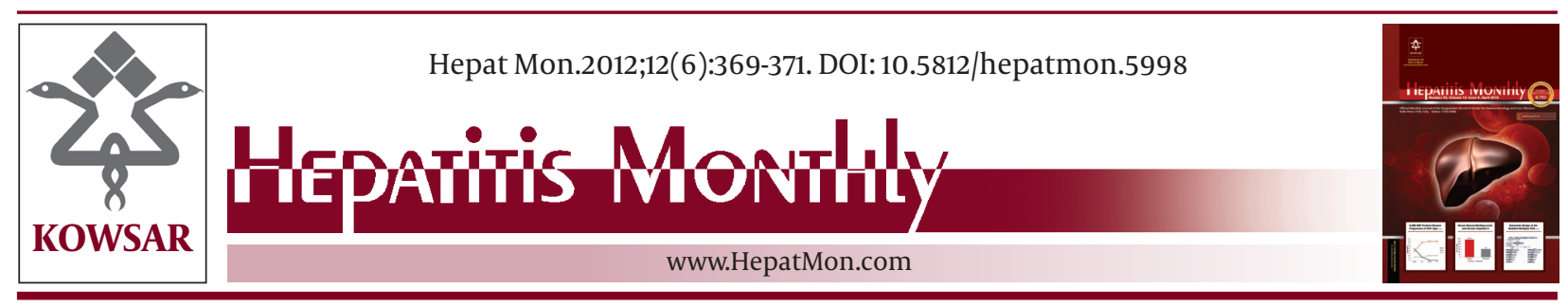

\title{
Statins in the Treatment of Hepatitis C
}

\author{
Cristin Constantin Vere ${ }^{1}$, Costin Teodor Streba ${ }^{1^{*}}$, Liliana Streba ${ }^{1}$, Ion Rogoveanu ${ }^{1}$ \\ ${ }^{1}$ Internal Medicine and Gastroenterology Department, University of Medicine and Pharmacy of Craiova, Craiova, Romania
}

\begin{tabular}{l}
\hline A R T I C L E I N F O \\
\hline Article type: \\
Editorial \\
\hline Article history: \\
Received: 17 Oct 2011 \\
Revised: 16 Jan 2012 \\
Accepted: 26 Feb 2012 \\
\hline Keywords: \\
Hepatitis C \\
Antiviral \\
Therapy
\end{tabular}

Hepatitis C virus (HCV) infection is an important health issue because it affects about $3 \%$ of the world population. It is estimated that $65-80 \%$ of HCV infections progress to chronic disease, and more than $20-50 \%$ of patients with chronic hepatitis develop hepatic cirrhosis. Hepatocellular carcinoma complicates $5 \%$ of the chronic hepatitis C cases $(1,2)$. Combination therapy with peginterferonribavirin, which is currently the standard treatment for chronic hepatitis C, shows a sustained virological response in $55 \%$ of patients. The remaining $45 \%$ of patients do not respond to antiviral therapy and are at risk of the HCV infection progressing to hepatic cirrhosis and hepatocellular carcinoma (3). In addition, because of the numerous adverse effects and possible contraindications to the use of combination therapy with peginterferon and ribavirin, the administration of this antiviral therapy is limited to only some patients with chronic hepatitis C (4). Because of these limitations, it is necessary to discover new therapeutic agents for eradicating HCV infection. Several recent studies have shown that statins, commonly used as cholesterol-lowering medication, can

* Corresponding author: Costin Tedor Streba,. Internal Medicine and Gastroenterology Department, University of Medicine and Pharmacy of Craiova, St. Petru Rares, No. 2, Craiova 200349, Dolj, Romania. Tel: +40741199792.E-mail:costinstreba@gmail.com

DOI:10.5812/hepatmon.5998

Copyright @2012 Kowsar Corp. All rights reserved.
- Please cite this paper as:

Vere CC, Streba CT, Streba L, Rogoveanu I. Statins in the Treatment of Hepatitis C. Hepat Mon. 2012;12(6): 369-71. DOI: 10.5812/ hepatmon.5998

Copyright $\odot 2012$ Kowsar Corp. All rights reserved.

inhibit the replication of $\operatorname{HCV}(3,5,6)$. Ikeda et al. (2) have reported in their 2006 study that statins can inhibit in vitro HCV replication. Using OR6 cells infected with HCV, the authors evaluated the antiviral activity of 5 statins: atorvastatin, fluvastatin, lovastatin, pravastatin, and simvastatin. All statins, except pravastatin, that were tested as monotherapy inhibited viral replication. Fluvastatin exhibited the strongest antiviral effect, whereas atorvastatin and simvastatin showed moderate inhibitory effects, and lovastatin exhibited a weak inhibitory effect on HCV replication. All of these statins exert a cholesterol-lowering effect by inhibiting the activity of 3-hydroxy3-methyl-glutaryl coenzyme A (HMG-CoA) reductase, an enzyme involved in cholesterol synthesis. Pravastatin, unlike the other tested statins, has no antiviral activity; hence, it inhibits HCV replication not by a direct action on HMG-CoA reductase, but by a specific antiviral mechanism (3). In order to emphasize the presence of an existing antiviral mechanism, the authors showed that the antiviral activity of statins is not due to hepatotoxicity; they proved so by demonstrating that HCV replication is not inhibited by the destruction of hepatocytes (3). Several in vivo studies have shown that the administration of statins in patients with chronic HCV infection is safe and has no severe adverse effects (7-9). For its replication, HCV requires a number of proteins, which are involved in cholesterol synthesis. Statins are considered to exert their antiviral activity by blocking these proteins. Thus, 
by inhibiting HMG-CoA reductase activity, statins reduce the intracellular concentration of geranylgeranyl pyrophosphate, which lowers the level of mevalonate necessary in cholesterol synthesis. A strong argument in favor of this theory is the fact that adding geranylgeraniol and mevalonate in cell cultures treated with statins leads to the restoration of viral replication.

In the same study, Ikeda et al. (2) evaluated the possibility of replacing ribavirin with statins in the treatment of chronic hepatitis $\mathrm{C}$. The efficacy of each tested statin was evaluated in combination therapy with interferon. All the statins, except pravastatin, showed higher inhibition of HCV replication when used in combination with interferon than when used as monotherapy. Interferon-fluvastatin combination therapy had the strongest antiviral effect, and the authors consider that this treatment is superior to standard therapy with interferon and ribavirin (3). Another recently published study (10), which evaluated in vitro anti-HCV activity of 5 statins, confirmed the Japanese authors' findings. According to these authors, mevastatin and simvastatin administered as monotherapy have the strongest antiviral activity; lovastatin and fluvastatin have a moderate antiviral effect, while pravastatin has no antiviral activity. In addition, mevastatin and simvastatin enhance the antiviral activity of interferon $\alpha$ and of drugs that inhibit viral replication; mevastatin also prevents or reduces resistance to therapy with viral replication inhibitors (10). Results of in vivo studies are controversial. According to the Initiating Dialysis Early and Late (IDEAL) study published in 2009, statins combined with peginterferon-ribavirin therapy significantly increase the sustained virological response rate, which is independent of serum lipid levels before the initiation of antiviral therapy. The findings of this retrospective study were not conclusive because of the small sample size; only 66 of the 3070 patients infected with HCV genotype 1 received treatment with statins (11). Another prospective study (12) on 31 patients with chronic hepatitis $\mathrm{C}$ infection has shown that fluvastatin alone (in commonly used doses) has a moderate, variable, and short-term antiviral effect. However, the findings of the in vivo studies were not consistent with those of the in vitro studies. In 2007, O'Leary et al. published a prospective study on 10 patients and reported that atorvastatin (in commonly used doses) does not inhibit viral replication (13). In 2009, Forde et al. (4) published a retrospective study including $6463 \mathrm{HCV}$ seropositive patients; this study showed that statins do not inhibit viral replication in vivo. According to these authors, the discrepancy between the results of the in vivo and in vitro studies may be attributable to several factors; one such factor is the low level of statins in the serum than in the cell cultures, because of the pharmacokinetic properties of statins. All statins, except pravastatin, are largely retained in the first pass through the liver. The in vitro anti-HCV action may be because of an adaptation of the cell cultures that makes the cells sensitive to interferon action and increases their sensitivity to statins. As an adaptive mechanism, HCV could undergo in vivo mutations and become resistant to statins; paradoxically, statins could exert proviral effects by promoting the expression of low-density lipoprotein (LDL) receptors, thereby facilitating HCV penetration into noninfected hepatocytes (4). Further, the same study showed that triglyceride-reducing agents, such as niacin, may have anti-HCV activity in vivo. There may be a direct relationship between triglyceride level and virus titer, considering that triglycerides metabolism is an intermediate step in the life cycle of HCV. The virus is released together with very low-density lipoprotein (VLDL) particles, and therefore, drugs such as niacin inhibit viral replication by lowering serum triglyceride levels (14-16).

Elucidating the role of statins in the treatment of chronic hepatitis $\mathrm{C}$ is important, and can be achieved by conducting prospective studies in large groups of patients. Extensive research is required to determine the effectiveness of triglyceride-reducing agents for inhibiting HCV replication. Until the approval of new therapeutic agents, the peginterferon-ribavirin combination represented the therapy of choice for chronic viral hepatitis C. Recent data have shown that the addition of protease inhibitors such as boceprevir or telaprevir to the classic peginterferon-ribavirin combination therapy decreases the duration of treatment, thereby reducing the cost of treatment and the number of adverse effects $(17,18)$. Further, an increase of up to $30 \%$ was observed in the sustained virological response rates in non-responders, with naïve and genotype $1 \mathrm{HCV}$ infection, and a corresponding increase of up to $40-50 \%$ was observed in patients showing relapse (19, 20). These recent advances have shown that statins play a role in improving treatment outcome and increasing the quality of life of HCV patients; however, the exact mechanism underlying their role is yet to be determined.

\section{Authors' Contribution}

Al authors contributed equally to preparing this manuscript.

\section{Financial Disclosure}

None declared.

\section{References}

1. Liang TJ, Rehermann B, Seeff LB, Hoofnagle JH. Pathogenesis, natural history, treatment, and prevention of hepatitis C. Ann Intern Med. 2000;132(4):296-305.

2. Gao B, Hong F, Radaeva S. Host factors and failure of interferonalpha treatment in hepatitis C virus. Hepatology.2004;39(4):88090.

3. Ikeda M, Abe K, Yamada M, Dansako H, Naka K, Kato N. Different anti-HCV profiles of statins and their potential for combination therapy with interferon. Hepatology. 2006;44(1):117-25.

4. Forde KA, Law C, O'Flynn R, Kaplan DE. Do statins reduce hepati- 
tis C RNA titers during routine clinical use? World J Gastroenterol. 2009;15(40):5020-7.

5. Ye J, Wang C, Sumpter R, Jr., Brown MS, Goldstein JL, Gale M, Jr Disruption of hepatitis $C$ virus RNA replication through inhibition of host protein geranylgeranylation. Proc Natl Acad Sci US A. 2003;100(26):15865-70.

6. Kapadia SB, Chisari FV. Hepatitis C virus RNA replication is regulated by host geranylgeranylation and fatty acids. Proc Natl Acad Sci U S A. 2005;102(7):2561-6.

7. Gibson K, Rindone JP. Experience with statin use in patients with chronic hepatitis C infection. Am J Cardiol. 2005;96(9):1278-9.

8. Khorashadi S, Hasson NK, Cheung RC. Incidence of statin hepatotoxicity in patients with hepatitis C. Clin Gastroenterol Hepatol. 2006;4(7):902-7; quiz 806.

9. Segarra-Newnham M, Parra D, Martin-Cooper EM. Effectiveness and hepatotoxicity of statins in men seropositive for hepatitis $C$ virus. Pharmacotherapy. 2007;27(6):845-51.

10. Delang L, Paeshuyse J, Vliegen I, Leyssen P, Obeid S, Durantel D, et al. Statins potentiate the in vitro anti-hepatitis $C$ virus activity of selective hepatitis $C$ virus inhibitors and delay or prevent resistance development. Hepatology. 2009;50(1):6-16.

11. Harrison SA, Rossaro L, Hu KQ, Patel K, Tillmann H, Dhaliwal $S$, et al. Serum cholesterol and statin use predict virological response to peginterferon and ribavirin therapy. Hepatology. 2010;52(3):864-74.

12. Bader T, Fazili J, Madhoun M, Aston C, Hughes D, Rizvi S, et al. Fluvastatin inhibits hepatitis $\mathrm{C}$ replication in humans. Am J Gastroenterol. 2008;103(6):1383-9.
13. O'Leary JG, Chan JL, McMahon CM, Chung RT. Atorvastatin does not exhibit antiviral activity against HCV at conventional doses: a pilot clinical trial. Hepatology. 2007;45(4):895-8.

14. Andre P, Komurian-Pradel F, Deforges S, Perret M, Berland JL, Sodoyer M, et al. Characterization of low- and very-lowdensity hepatitis C virus RNA-containing particles. J Virol. 2002;76(14):6919-28.

15. Nielsen SU, Bassendine MF, Burt AD, Martin C, Pumeechockchai W, Toms GL. Association between hepatitis C virus and very-lowdensity lipoprotein (VLDL)/LDL analyzed in iodixanol density gradients.J Virol. 2006;80(5):2418-28.

16. Nahmias Y, Goldwasser J, Casali M, van Poll D, Wakita T, Chung RT, et al. Apolipoprotein B-dependent hepatitis C virus secretion is inhibited by the grapefruit flavonoid naringenin. Hepatology. 2008;47(5):1437-45.

17. Corouge M, Pol S. New treatments for chronic hepatitis $C$ virus infection. Med Mal Infect. 2011;41(11):579-87.

18. Kumada H, Toyota J, Okanoue T, Chayama K, Tsubouchi H, Hayashi N. Telaprevir with peginterferon and ribavirin for treatmentnaive patients chronically infected with $\mathrm{HCV}$ of genotype 1 in Japan.J Hepatol. 2012;56(1):78-84.

19. Poordad F, McCone J, Jr., Bacon BR, Bruno S, Manns MP, Sulkowski MS, et al. Boceprevir for untreated chronic HCV genotype 1 infection. N Engl J Med. 2011;364(13):1195-206.

20. Bacon BR, Gordon SC, Lawitz E, Marcellin P, Vierling JM, Zeuzem $\mathrm{S}$, et al. Boceprevir for previously treated chronic HCV genotype 1 infection. N Engl J Med. 2011;364(13):1207-17. 